\title{
Burnout syndrome in gerontological nursing: review of the theoretical and practical perspectives
}

\author{
Síndrome de burnout en enfermería geriátrica: revisión de las perspectivas teóricas y \\ prácticas
}

\author{
Síndrome de Burnout na enfermagem geriátrica: uma revisão das perspectivas teóricas e \\ práticas
}

\author{
Jacqueline Hernández-Sánchez ${ }^{{ }^{*}}$ \\ Katherine del Consuelo Camargo-Hernández ${ }^{2}$
}

\begin{abstract}
Introduction: Analyze the theoretical and practical perspectives shown in global scientific publications, regarding the burnout syndrome in the nursing staff that provide care to the elderly population. Methodology: A review of the literature was made for the global context of published articles in English and Spanish, from the databases of ScienceDirect, the Virtual Health Library (VHL), Dialnet and Redalyc, during the period from 2013 to 2018. Results: 15 publications met the selection criterion. The majority of the original articles had as their objective to identify the correlation between the burnout syndrome and the workload or work stress; only one article reports the evaluation of an intervention. None of the articles refer to gerontological nursing as part of the construct from which their studies are based on; but the majority do define the term burnout. Conclusions: The reviewed scientific evidence about burnout in gerontological nursing is scarce, which encourages to investigate more about the subject, as well as publishing. Also, it is necessary to make these constructs explicit. The results suggest future improvements for studies related to their objectives, the methodology used and the interventions.
\end{abstract}

Palabras clave: Gerontological nursing; geriatric; work burnout; retirement home.

\section{Resumen}

Introducción: Analizar las perspectivas teóricas y prácticas que muestran las publicaciones científicas a nivel mundial, con respecto al síndrome de burnout, en el personal de enfermería que ofrece cuidado a la población adulta mayor. Metodología: Se realizó una revisión de literatura en el contexto mundial de artículos publicados en inglés y español, en las bases de datos de ScienceDirect, Biblioteca Virtual en SaludBVS, Dialnet y Redalyc, en el período de 2013 a 2018. Resultados: 15 publicaciones que cumplían con los criterios de inclusión. La mayoría de los artículos originales tenían como objetivo identificar la correlación entre el síndrome de quemarse por el trabajo o estresores laborales; solamente un artículo reporta la evaluación de una

\section{Autor de correspondencia}

${ }^{1 *}$ Nurse. M. Sc in Educational Technology and Innovation in Education. Part time professor. Nursing Faculty. Cooperative University of Colombia. Bucaramanga, Colombia. E-mail: jacqueline.hernandezsa@campusucc.edu.co (iD)

${ }^{2}$ Nurse. M. Sc in Nursing Sciences. Fulltime professor. Nursing Faculty. Cooperative University of Colombia. Bucaramanga, Colombia. E-mail: katherine.camargoh@campusucc.edu.co iD

(C) Universidad Francisco de Paula Santander. Este es un artículo bajo la licencia CC-BY-NC-ND

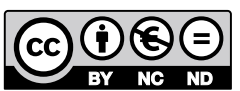

Received: November 14, 2019 Approved: April 2, 2020

\section{Para citar este artículo/ To reference this article / Para citar este artigo/}

Hernández-Sánchez Jacqueline; Camargo-Hernández Katherine del Consuelo. Burnout syndrome in gerontological nursing: review of the theoretical and practical perspectives. Rev. cienc. cuidad. 2020; 17(2): 77-87. https://doi.org/10.22463/17949831.1578 
ISSN-PRINT

1794-9831

E-ISSN 2322-7028

Vol. 17 No. 2

May - Ago 2020

Cúcuta, Colombia

intervención. En ninguno de los artículos se hace referencia a la enfermería geriátrica, como parte del constructo en el que se basa el estudio; pero la mayoría sí definen el burnout. Conclusiones: La evidencia científica revisada sobre el burnout en enfermería geriátrica es escasa, lo cual reta a investigar más, así como a publicar. También es necesario hacer explícitos estos dos constructos. Los resultados sugieren mejoras para futuros estudios en relación con los objetivos, la metodología y las intervenciones.

Palabras clave: Enfermería geriátrica; burnout en el trabajo; hogares para ancianos.

\section{Resumo:}

Introdução: Analisar as perspectivas teóricas e práticas evidenciadas na literatura científica mundial, relacionada com a síndrome de Burnout no pessoal da enfermagem que presta cuidados na populaçao idosa. Métodos: Realizou-se uma revisão de literatura internacional de artigos publicados em inglês e espanhol disponíveis em ScienceDirect, Biblioteca Virtual em Saúde-BVS, Dialnet e Redalyc, no período de 2013 ao 2018. Resultados: 15 artigos cumpriram os critérios de elegibilidade. A maioria desses tinham como objetivo identificar a correlação entre o Burnout e situações estressoras no trabalho; somente um artigo reportou a avaliação de uma intervenção. Nenhum fazia referência à enfermagem geriátrica, que a variável de interesse do presente estudo; entretanto a maioria definia o Burnout. Conclusões: A evidência científica revisada relacionada com o Burnout na enfermagem geriátrica é escassa, evidenciando uma área que precisa de pesquisa e de publicação de resultados na mesma. Também precisa-se fazer maior ênfase nessas duas variáveis. Os resultados sugerem melhoras para futuros estudos relacionados com os objetivos, a metodologia e as intervenções.

Palavras-chave: Enfermagem geriátrica; Burnout no trabalho; esgotamento do cuidador; serviços de saúde para idosos.

\section{Introduction}

For many years, the occupational burnout syndrome has been studied; it is considered a "extreme fatigue and it is characterized by the experience of emotional tiredness, feeling reduced professional efficacy and low personal realization, as well as experiencing depersonalization (1)". These emotional and intrapersonal manifestations generally appear in professionals who have direct contact with users at work (2), with whom they establishing intense and indefinite interactions (3). From the psychosocial perspective, burnout is conceived as a result from chronic workplace stress, linked to social relationships between service providers and the receptors of the services; it is a mechanism of confrontation and self-protection towards stress, generated by these relationships (4). The main causal factors are work overload, lack of autonomy, indetermination and conflict about their role (5), evidenced by the fatigue of the professionals, which is defined as "a functional state of protective significance that produces the unpleasant physical feeling of burnout, including the cognitive and emotional components (6)". The effects of work stress may vary from one person to another, causing cardiovascular, mental, brain damaging, and reproductive diseases, musculoskeletal disorders, as well as problems related to the abuse of drugs and alcohol, sleep disorders and sedentarism. The need of studying occupational burnout is associated to the protection the health rights of the worker, because they are an important part of the organization (7); and even, some researchers of the subject consider it a professional disease (8-9). For their part, Arias and Benitez (10) mention that professions that are focused on providing services have a high vulnerability to develop occupational burnout. Currently, the World Health Organization (WHO) considers the professionals from this area as highly stressed (10), among them, those who work in nursing.

The manifestations of the presence of this syndrome in the nursing staff, is generally expressed with negative behaviors, cynicism, desperation or emotional exhaustion, and personal unfulfillment when providing care on the users (11). Similarly, this syndrome manifests itself with negative behaviors toward the organization, which are reflected by distancing behaviors, indifference, and coldness when doing nursing care activities (12). Also, Gutierrez et al., (13) mention that absenteeism from the nursing staff has a significant relationship with work stress and the burnout syndrome, generating an increase in the costs of the healthcare system, organization problems in the healthcare institutions and difficulties in the care of the users. 
The burnout syndrome in nursing, has been extensively studied, especially in the areas of care for critical patients in services such as intensive care and emergency care (14-23). It has also been studied in staff who work in primary healthcare (24-26); however, there are no-known studies related to burnout for geriatric nursing. Nursing care for the elder population merits specialized care since ageing is considered a normal and irreversible process of humans, a life stage where environment, biological and psychosocial changes occur and require of this type of care (27). While it is true that there is no consensus about the definition of gerontological nursing, it can be called differently, for example, geriatric nursing (28); it can be assumed that the conceptualization given by the Pan American Health Organization (PAHO) (29) is still valid. The PAHO describes gerontological nursing as:

"a health service that adds to the specific knowledge of nursing, the specialized knowledge about the aging process, to establish in the elderly person and his or her environment, conditions that allow: to increase the health conditions; minimize and compensate health losses and the limitations related to age; provide comfort during aging-associated anxiety events and weakness, including the process of death; and facilitate the diagnosis, alleviation and treatment of old aging-associated diseases"

Considering the importance that the occupational burnout syndrome has in nursing, especially, in the care of elderly people, as well as the fact that it is unknown how much and what has been researched on and written about this subject in scientific publications, this study was proposed, with the objective of analyzing the theoretical and practice perspectives that the scientific publications show globally, regarding the burnout syndrome in gerontological nursing staff. This work is considered to be important since it will allow to trace a course of action in future researches about this subject, that contribute to further examine this phenomenon as well as creating effective interventions.

\section{Methodology}

A background information review was made. Although, this type of research is located at the bottom of the hierarchy pyramid of research evidence (30), its main purpose is to identify, analyze, value and interpret the body of knowledge about a specific subject. Its value consists of the contributions made related to the evaluation of the practices, the study of conceptual and theoretical frameworks, as well as generating new ideas, and highlighting the current incoherencies in the field of knowledge (31-32). The research was made for the global context of published articles in the databases of ScienceDirect, the Virtual Health Library (VHL), Dialnet and Redalyc, with publication dates from 2013 to 2018.

The research for article publications was made from April to June of 2018. Two researchers participated as directors of the project, and two students as auxiliary researchers. The inclusion criteria considered for the articles were original research and review articles, related to gerontological nursing and the burnout syndrome. The exclusion criteria were dissertations, thesis, case studies, and researches with focus on the burnout syndrome in areas different from gerontological nursing.

The bibliographic research was made on databases using keywords according to the established in the descriptors of health sciences, these were: gerontological nursing, burnout, retirement homes; also using the Boolean Operator AND the following way: gerontological nursing AND burnout AND retirement home.

\section{Analysis}

A total of 201 articles were found, out of these, only 15 publications were chosen (33-47) (12 original publications and 3 reviews) that met the inclusion criterion established for this review (Table 1) (Figure 1). The findings on this review reflect that, globally, the publication of original and review articles about burnout in gerontological nursing. The years with more publications were 2014 and 2016; being the countries with most publications Spain, followed by Germany. In America, publications on this subject were found in The United States, Mexico, and Peru (Table 1). 
ISSN-PRINT

1794-9831

E-ISSN 2322-7028

Vol. 17 No. 2

May - Ago 2020

Cúcuta, Colombia
Table 1. Articles included in the review.

\begin{tabular}{|c|c|c|c|c|c|c|c|}
\hline \multirow[b]{2}{*}{ Database } & \multirow[b]{2}{*}{ Title of the article } & \multirow{2}{*}{$\begin{array}{l}\text { Year of } \\
\text { publica- } \\
\text { tion }\end{array}$} & \multirow[b]{2}{*}{ Country } & \multirow{2}{*}{$\begin{array}{l}\text { Tyoe of } \\
\text { study }\end{array}$} & \multirow[b]{2}{*}{ Instrument used } & \multicolumn{2}{|c|}{ Type of article } \\
\hline & & & & & & Original & Review \\
\hline $\begin{array}{l}\text { Virtual } \\
\text { Health } \\
\text { Library - } \\
\text { VHL }\end{array}$ & $\begin{array}{l}\text { Job demands and personal resources in their rela- } \\
\text { tions to indicators of job strain among nurses for } \\
\text { older people (40) }\end{array}$ & 2013 & $\begin{array}{l}\text { Nether- } \\
\text { lands }\end{array}$ & $\begin{array}{l}\text { Cross- } \\
\text { sectional }\end{array}$ & Survey & $\mathrm{X}$ & \\
\hline Redalyc & $\begin{array}{l}\text { Sobrecarga y Burnout en cuidadores informales del } \\
\text { adulto mayor }(27)\end{array}$ & 2014 & Mexico & $\begin{array}{l}\text { Cross- } \\
\text { sectional } \\
\text { - correla- } \\
\text { tional }\end{array}$ & $\begin{array}{l}\text { QuestionnaireMas- } \\
\text { lach Burnout Inven- } \\
\text { tory (MBI) }\end{array}$ & $X$ & \\
\hline Redalyc & $\begin{array}{l}\text { Síntomas somáticos en cuidadores de pacientes } \\
\text { geriátricos con o sin sobrecarga, del área urbano- } \\
\text { marginal Payet, Independencia, Lima, Perú (41) }\end{array}$ & 2014 & Peru & $\begin{array}{c}\text { Cross- } \\
\text { sectional } \\
\text { correlatio- } \\
\text { nal }\end{array}$ & $\begin{array}{l}\text { Zarit Burden Inter- } \\
\text { view }\end{array}$ & $\mathrm{X}$ & \\
\hline $\begin{array}{l}\text { Science } \\
\text { Direct }\end{array}$ & $\begin{array}{l}\text { La evaluación de la carga del cuidador: una revi- } \\
\text { sión más allá de la escala de Zarit(42) }\end{array}$ & 2014 & Spain & $\begin{array}{l}\text { Systematic } \\
\text { review }\end{array}$ & $\mathrm{N} / \mathrm{A}$ & & $X$ \\
\hline $\begin{array}{l}\text { Science } \\
\text { Direct }\end{array}$ & $\begin{array}{l}\text { Burnout in the field of geriatric medicine: Review } \\
\text { of the literature (33)the factors explaining this } \\
\text { prevalence, and to describe interventions to pre- } \\
\text { vent burnout among healthcare workers in geri- } \\
\text { atric care. Material and methods: The MEDLINE } \\
\text { and PubMed databases were searched for articles } \\
\text { published between } 1980 \text { and } 2013 \text {. The following } \\
\text { MeSH terms were used to identify factors explain- } \\
\text { ing burnout: Geriatric; long term care; nursing } \\
\text { home; nurse; doctor; nurse in training or physician } \\
\text { in training; physician; home help; elderly person; } \\
\text { resident; dementia; intervention; occupational } \\
\text { and/or emotional exhaustion; burnout; MBI. Only } \\
\text { studies performed in the context of geriatric care } \\
\text { were retained. Result: There are many studies in } \\
\text { the literature pertaining to burnout, but few focus } \\
\text { particularly on the specific environment of geriatric } \\
\text { care. Overall, } 12 \text { articles were selected that evaluat- } \\
\text { ed burnout using self-administered questionnaires. } \\
\text { Many factors combine to explain the existence } \\
\text { of burnout among healthcare workers in geriatric } \\
\text { medicine: Extrinsic (environmental }\end{array}$ & 2014 & France & $\begin{array}{l}\text { Systematic } \\
\text { review }\end{array}$ & $\mathrm{N} / \mathrm{A}$ & & $\mathrm{X}$ \\
\hline $\begin{array}{l}\text { Science } \\
\text { Direct }\end{array}$ & $\begin{array}{l}\text { Burnout intervention studies for inpatient elderly } \\
\text { care nursing staff: Systematic literature review (34) }\end{array}$ & 2014 & Germany & $\begin{array}{l}\text { Systematic } \\
\text { review }\end{array}$ & $\mathrm{N} / \mathrm{A}$ & & $\mathrm{X}$ \\
\hline
\end{tabular}

The satisfaction with the quality of dementia care Science and the health, burnout and work ability of nursDirect es: A longitudinal analysis of 50 German nursing homes (43)

The impact of job stressors on health-related quality of life of nursing assistants in long-term care settings(44)

The influence of work characteristics, emotional display rules and affectivity on burnut and job satisfaction: A survey among geriatic care workers (45)little research has been done on the role played by perceptions of emotional display rules, alongside more traditional work characteristics and individual factors, in the prediction of geriatric care employees' wellbeing. Objectives The aim of the present study was to examine the role played by work characteristics (job demands, job control, emotional display rules
Cross-sec-

2014 Germany tional-Descriptive

Cross-sectional- correlational

Cross-

2016 France sectional -descriptive
Self-informed ques tionnaire based in the questionnaire "European nurses"

Job stressors

(C-JCQ)
$\mathrm{X}$ 


\section{,}

ISSN-PRINT

1794-9831

Relación entre estrés y calidad de vida en profe-

Dialnet sionales del área psicogeriátrica como medidor de intervención para mejora en el clima laboral (35)

Efectos de una intervención cognitivo-conductual

Redalyc para disminuir el burnout en cuidadores de ancianos institucionalizados (46)

Virtual

Health

Library

- VHL/

Dialnet

Cuidados paliativos gerontológicos: influencia de las condiciones laborales y burnout en el personal de enfermería (47)

Which resources moderate the effects of demanding work schedules on nurses working in residential elder care? A longitudinal study (48)health and well-being. Objectives: This longitudinal study examined whether the interactions of personal and job resources with work schedule demands predicted work engagement and emotional exhaus-

Virtual tion in nursing. Design: This longitudinal study

Health included two waves of data collection with a one

Library - year follow-up using self-report questionnaires

VHL among 247 nurses working shifts or irregular working hours in residential care for the elderly in the Netherlands. Methods: Moderated structural equation modelling was conducted to examine the interactions between personal and job resources and work schedule demands. Two work schedule demands were assessed: type of work schedule (demanding vs. less demanding

Science Compassion fatigue among nurses working with

Direct older adults (49)

Are nursing home care workers' health and presenteeism associated with implicit rationing of

Science care? A cross-sectional multi-site study (50)rationing of care occurred "never" to "seldom." Rationing of activities of daily living was positively associated with care workers' joint pain ( $\beta 0.04$,
Spain

Cross-

sectional, descriptive

Maslach Burnout

Inventory (MBI)

$\mathrm{X}$

Spain Cuasi-ex- evaluar el síndrome perimental

de quemarse por el trabajo (CESQT)

Crosssectional, descriptive
Maslach Burnout

Inventory (MBI)
Cuestionario para

\section{$\mathrm{X}$}

X
Nether-

lands
Longitudi-
nal- correlational
Cuestionario

Maslach Burnout

Inventory (MBI)
X

Cross- sectional, descriptive

\section{Quality of Life} (ProQQL)

Switzer- Crossland, Italy sectional and Bel- - correlagium
E-ISSN 2322-7028

Vol. 17 No. 2

May - Ago 2020

Cúcuta, Colombia CI 0.001-0.07

Source: Made by the authors 
ISSN-PRINT

1794-9831

E-ISSN 2322-7028

Vol. 17 No. 2

May - Ago 2020

Cúcuta, Colombia

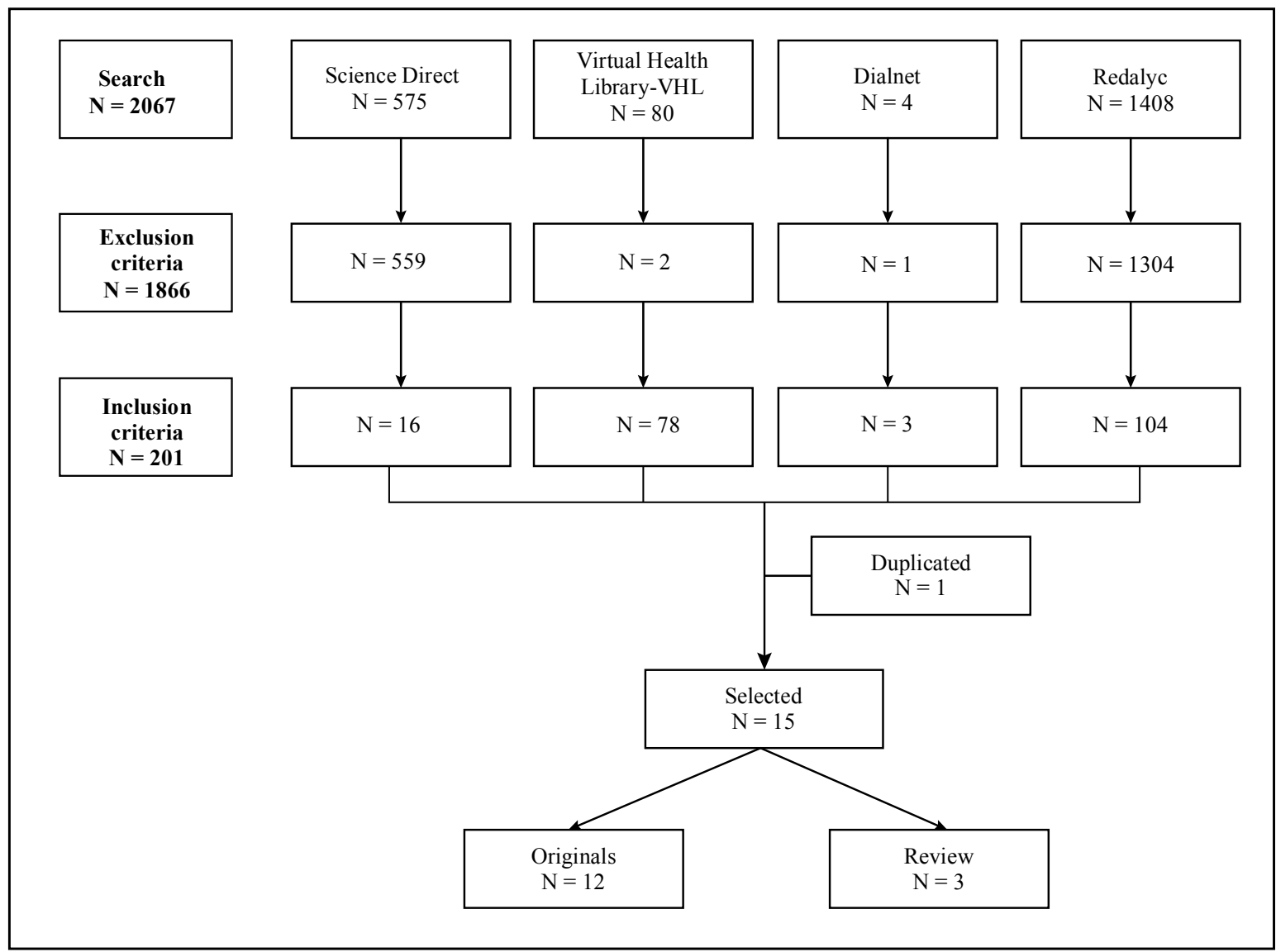

Figure 1. Research and selection of articles

Source: Made by the authors.

A result of the review were the emerging categories described below, considering the following thematic focuses: theoretical perspectives of burnout in geriatric nursing and the practice perspectives of burnout in geriatric nursing.

\section{Theoretical perspectives of burnout in gerontological nursing}

Absence of the gerontological nursing concept. None of the articles mention gerontological nursing as part of the concept from which their studies are based on. This omission of inclusion of a theoretical framework about the subject, marks a common error which is key for research, since it is necessary to include a theory that can be used as a reference in the research process, also connecting the rest of the components: problem, methodology and results (36); especially since there is no consensus about its definition (28).

Burnout theorical consensus: In relation to the burnout concept, the majority of articles define it and related it to the following characteristics: it is a syndrome of intrapersonal and emotional character; it has a great number of unspecific symptoms; it is caused by work stress in staff who provide care services; it has health consequences in the person as well as affecting their work performance. Generally, the studies are supported by the proposals of the author itself. Regarding the development of the theoretical concept of burnout, it is observed that this concept is more evident in the majority of articles reviewed; likewise, this review identified conceptual approaches about this subject when relating it to negative emotional aspects, product of work performance, that also affect the health of the person. These theoretical postures are key for the introduction, where they should be included, as said by Cortes (37) these are "the cover letter of an article".

\section{Practice perspectives of burnout in gerontological nur- sing}

In the practice, burnout studies in gerontological nursing are qualitatively measured. The objectives in the majority of the 12 original articles are oriented to 
identify a correlation between occupational burnout or sources of stress with variables such as: satisfaction, years of experience, work environment, self-efficacy, professional quality of life and other sociodemographic variables. One of the publications shows the results of a study that evaluated the effects of a cognitive behavioral intervention to decrease burnout aimed at formal geriatric care staff.

Regarding the 3 review articles, 2 of them were focused on the identification of literature about burnout and the description of interventions aimed at geriatric nursing staff; however, the other article was related to the review of the evaluation scales of workload for the caregiver, used in the gerontological context. The abovementioned shows that the main purpose of the studies from the articles that were included for this background information review, are related to the interventions used to determine the factors that are correlated with burnout in geriatric nursing staff, however, the publications that report effectiveness of the interventions for burnout in geriatric nursing staff are scarce.

Regarding the methods used, in the original articles prevails the quantitative focus, where two main types of studies were applied: cross-sectional descriptive study and cross-sectional correlational study. For the review articles, the systematic and literature review is described as the methodology. Likewise, in the literature review made by Sanchez et al., (33) between 1980 and 2013, it is reported that the studies used this method and the majority were cross-sectional studies. The challenge now is assuming a more comprehensive research approach that allows the understanding of the phenomenon of study beyond the contributions from the quantitative methods; in other words, gerontological nursing burnout can be studied from the phenomenological and constructivist perspective or integrating this with the positivist perspective, using mixed methods.

The use of Maslach Burnout Inventory (MBI) prevails. The majority of the original articles that mention the measurement of burnout also mention the use of the MBI; another study used the Spanish Burnout Inventory (CESQT). However, other articles do not measure burnout with a specific instrument, their studies are oriented to evaluate the professional quality of life and the satisfaction with the care quality. Similarly, other literature review articles that were found inform about the use of the MBI, as an instrument of preference for the measurement of the burnout syndrome (33-34). Although the evidence found shows a frequent use of the instrument; its also necessary to consider the mentioned by other studies, for example, the study of Kulakova et al., (38) who came to the conclusion that the MBI construct, has significant inconsistencies in the dimensions of depersonalization and personal realization, as well as limitations to the universalization of its use among heterogenous cultures. This authors also recommend the use of the qualitative method to discover the specific configuration of burnout, which is affected by the sociocultural context.

Scarce report of burnout interventions for geriatric nursing staff. Only one article reports an intervention made on caregivers from a retirement home, evaluating burnout. This intervention consisted of making a cognitive-behavioral, educational intervention (relaxation, cognitive restructuration, social abilities and positive reinforcement, shaping and modeling), through 9 individual sessions and with the support on two manuals, one directed to the facilitator and the other to the participants (35).

Differing from the abovementioned, from the systematic review made by Westermann et al. and the literature review by Sanchez et al., (33-34), it was found that the majority of the interventions directed to the caregivers affected by burnout are mainly focused in developing a training of knowledge and management of senior adults with pathologies such as dementia; few interventions included aspects related to ergonomic, teamwork, communication and management of emotions programs. It becomes necessary to have better educational and pedagogical basis, as well as the prevention and management of nursing burnout.

According to this, this review shows that the results of burnout interventions for geriatric nursing staff are scarce, although some review articles do report these types of interventions. It stands out that the focus of the majority of these researches are especially oriented to the development of knowledge and the management of elderly patients, but the orientation towards the development of nursing competences to allow nursing staff to solve this syndrome is scarce. None of these actions are preventive. In the work of Racionero (39), the existing limitations are mentioned, considering that the majority of the burnout intervention strategies have the purpose of developing knowledge about the subject but do not study the cause of burnout, nor propose solutions. 


\section{Conclusions}

- The globally published scientific evidence regarding the burnout syndrome caused by working as nursing staff who provide care to the elder population is scarce, a finding that challenges for more research on this subject. Also, it is important to explicitly include the constructs about gerontological nursing and burnout in which the studies are based on.

- The findings of the scientific articles about burnout in geriatric nursing staff from the practice perspective, suggest improvements in the objectives of future researches; the diagnosis of this syndrome and the factors that determine it should not be the only focus of these studies, there should be advances in the evaluation of effectiveness of intervention strategies for its prevention and treatment. Also, it is important to use qualitative or mixed methods that contribute to a wider perspective of the phenomenon of study: as well as reviewing the sociocultural relevance of the instruments used.

- On the other hand, the intervention strategies of the caregivers of elderly people, should not only be oriented to getting a greater understanding of the subject, but also, to the development of attitudes and abilities to be more competent when they are already affected by this syndrome or when they are at risk.

- Lastly, it is important to divulge the results of the research, since it is the only way of contributing to the development of knowledge, and to the prevention and management of burnout in elderly care nursing staff.

\section{Conflict of interests}

The authors declare not having any conflict of interests.

\section{References}

1. Marín-Tejada M. Prevención de burnout y fatiga por compasión: evaluación de una intervención grupal. Journal of Behavior Health \& Social Issues. 2017; 9:117-123. Doi: https://doi.org/10.1016/j.jbhsi.2018.01.008

2. Buzzetti M. Validación del Maslach Burnout Inventory (MBI), en dirigentes del colegio de profesores A.G. de Chile. [Tesis]. Santiago de Chile: Universidad de Chile; 2005.

3. Vilá M, Cruzate C, Orfila F, Creixell J, González M, Davins J. Burnout y trabajo en equipo en los profesionales. Atención primaria. 2015; 47(1): 25-31. doi: https://doi.org/10.1016/j.aprim.2014.01.008

4. Diaz-Bambula F, Gómez IC. La investigación sobre el síndrome de burnout en Latinoamérica entre 2000 y el 2010. Psicología desde el Caribe. 2016; 33(1):113-131.

5. Patlán J. Efecto del burnout y la sobrecarga en la calidad de vida en el trabajo. Estudios gerenciales. 2013; 29: 445-455.

6. Seguel F, Valenzuela S. Relación entre la fatiga laboral y el síndrome burnout en personal de enfermería de centros hospitalarios. Enfermería Univ. 2014; 11(4):119-27.

7. Fidalgo-Vega M. NTP 704: Síndrome de estar quemado por el trabajo o «burnout» (I): definición y proceso de generación. Ministerio de Trabajo y Asuntos Sociales de España. Instituto Nacional de Seguridad e Higiene en El Trabajo. 2003; 1-7.

8. Gil-Monte PR. Riesgos psicosociales en el trabajo y salud ocupacional. Rev. perú. med. exp. salud pública. 2012; 29(2):237-41.

9. Moreno-Jiménez B. Factores y riesgos laborales psicosociales: conceptualización, historia y cambios actuales. Med Segur Trab. 2011; 57(1):4-19.

10. Arias F, Benítez O. Burnout o el agotamiento profesional. Inventio. 2007; 6(3):55-62.

11. Marilaf M, San-Martín M, Delgado-Bolton R, Vivanco L. Empatía, soledad, desgaste y satisfacción personal en Enfermeras de cuidados paliativos y atención domiciliaria en Chile. Enfermería Clínica. 2017; 27(6): 379-386. Doi: https://doi.org/10.1016/j.enfcli.2017.04.007 
12. Domínguez J, Herrera F, Villaverde M, Padilla I, Martínez M, Domínguez J. Síndrome de desgaste profesional en trabajadores de atención a la salud en el área sanitaria de Ceuta. Atención primaria. 2012; 44 (1):30-35. Doi: https://doi.org/doi:10.1016/j.aprim.2011.01.004

13. Blanca-Gutierrez J, Jiménez-Díaz M, Escalera-Franco L. Intervenciones eficaces para reducir el absentismo del personal de enfermería hospitalario. Gaceta Sanitaria. 2013; 27(6):545-551. Doi: https://doi. org/10.1016/j.gaceta.2012.09.006

14. Rodríguez-López AI, Méndez-Durán A. Síndrome de burnout en profesionales de enfermería de áreas críticas en un hospital de tercer nivel. Gac Med Bilbao. 2016; 113(3):99-104.

15. Martín RA. Burnout en enfermería: prevalencia y factores relacionados en el medio hospitalario. Rev Cient Soc Esp Enferm Neurol. 2015; 41(1):9-14. Doi: https://doi.org/10.1016/j.sedene.2015.02.001

16. Arrogante Ó. Mediación de la resiliencia entre burnout y salud en el personal de enfermería. Enfermería Clínica. 2014; 24(5):283-9. Doi: https://doi.org/10.1016/j.enfcli.2014.06.003

17. Albendín L, Gómez JL, Cañadas GA, Cañadas GR, San Luis C, Aguayo R. Prevalencia bayesiana y niveles de burnout en enfermería de urgencias. Una revisión sistemática. Revista Latinoamericana de Psicología. 2016; 48(2):137-45. Doi: https://doi.org/10.1016/j.rlp.2015.05.004

18. Seguel F, Valenzuela $S$. Relación entre la fatiga laboral y el síndrome burnout en personal de enfermería de centros hospitalarios. Enfermería Univ. 2014; 11(4):119-27. Doi: https://doi.org/10.1016/S16657063(14)70923-6

19. Ríos-Risquez MI, Godoy-Fernández C, Peñalver-Hernández F, Alonso-Tovar AR, López-Alcazar F, LópezRomera A, et al. Estudio comparativo del burnout en personal de enfermería de cuidados intensivos y urgencias. Enfermería Intensiva. 2008; 19(1):2-13. Doi: https://doi.org/10.1016/S1130-2399(08)72738-X

20. Fuentelsaz-Gallego C, Moreno-Casbas T, Gómez-García T, González-María E. Entorno laboral, satisfacción y burnout de las enfermeras de unidades de cuidados críticos y unidades de hospitalización. Proyecto RN4CAST-España. Enfermería Intensiva. 2013; 24(3):104-12. Doi: https://doi.org/10.1016/j.enfi.2013.06.001

21. Frade-Mera MJ, Vinagre-Gaspar R, Zaragoza-García I, Viñas-Sánchez S, Antúnez-Melero E, ÁlvarezGonzález S, et al. Síndrome de burnout en distintas unidades de cuidados intensivos. Enfermería Intensiva. 2009; 20(4):131-40. Doi: https://doi.org/10.1016/S1130-2399(09)73221-3

22. Chuang $\mathrm{CH}$, Tseng PC, Lin $\mathrm{CY}$, Lin $\mathrm{KH}$, Chen YY. Burnout in the intensive care unit professionals: A systematic review. Medicine (Baltimore). 2016; 95(50):e5629. Doi: https://doi.org/10.1097/ MD.0000000000005629

23. Akman O, Ozturk $\mathrm{C}$, Bektas $\mathrm{M}$, Ayar D, Armstrong MA. Job satisfaction and burnout among paediatric nurses. J Nurs Manag. 2016; 24(7):923-33. Doi: https://doi.org/10.1111/jonm.12399

24. Gómez-Urquiza JL, Monsalve-Reyes CS, Luis-Costas CS, Fernández-Castillo R. Factores de riesgo y niveles de burnout en enfermeras de atención primaria : una revisión sistemática. Atención Primaria. 2017; 49(2):77-85. Doi: https://doi.org/10.1016/j.aprim.2016.05.004

25. Tomás-Sábado J, Maynegre-Santaulária M, Pérez-Bartolomé $M$, Alsina-Rodríguez $M$, Quinta-Barbero R, Granell-Navas S. Síndrome de burnout y riesgo suicida en enfermeras de atención primaria. Enfermería Clínica. 2010; 20(3):173-178. Doi: https://doi.org/10.1016/j.enfcli.2010.03.004

26. Helfich CD, Simonetti JA, Wood GB, Taylor L, Schectman G, Stark R, et al. La asociación de carga de trabajo específica del equipo y personal con probabilidades de agotamiento entre los miembros del equipo de atención primaria del VA. Rev Med Interna Gen. 2017; 32(7):760-766

27. De Valle-Alonso MJ, Hernández-López IE, Zúñiga-Vargas ML, Martínez-Aguilera P. Sobrecarga y Burnout en cuidadores informales del adulto mayor. Enfermería Univ. 2015; 12(1):19-27. Doi: https://doi. org/10.1016/j.reu.2015.05.004

28. Batchelor N, Bird L, Cable W. Enfermería gerontológica. 8a ed. Linppincott Williams, editor. Inglaterra; 2014. 
ISSN-PRINT

$1794-9831$

E-ISSN 2322-7028

Vol. 17 No. 2

May - Ago 2020 Cúcuta, Colombia
29. Anzola-Pérez E. Enfermería gerontológica: conceptos para la práctica. Organización Panamericana de la Salud Organización Mundial de la Salud. Washington, E.U.A.; 1993.

30. Cardona-Arias JA, Higuita-Gutiérrez LF, Ríos-Osorio LA. Revisiones sistemáticas de la literatura científica. Revisiones sistemáticas de la literatura científica: la investigación teórica como principio para el desarrollo de la ciencia básica y aplicada. 2016. Bogotá: Ediciones Universidad Cooperativa de Colombia.

31. Aveyard H. Doing a literature review in health and social care: A practical guide. $3^{\mathrm{a}}$ ed. Bershire, England: McGraw-Hill Education; 2014.

32. Guirao Goris Silamani A. Utilidad y tipos de revisión de literatura. Ene. [Internet]. 2015 [citado 2019 Feb 14]; 9(2). Doi: http://dx.doi.org/10.4321/S1988-348X2015000200002

33. Sanchez S, Mahmoudi R, Moronne I, Camonin D, Novella JL. Burnout in the field of geriatric medicine: Review of the literature. European Geriatric Medicine. 2015; 6(2):175-83. Doi: https://doi.org/10.1016/j. eurger.2014.04.014

34. Westermann C, Kozak A, Harling M, Nienhaus A. Burnout intervention studies for inpatient elderly care nursing staff : systematic literature review. Int J Nurs Stud. 2014; 51(1):63-71. Doi: https://doi.org/10.1016/j. ijnurstu.2012.12.001

35. Sarabia-Cobo CM, Diez-Saiz Z, Salado-Morales L, Clemente-Campo V. Relación entre estrés y calidad de vida en profesionales del área psicogeriátrica como medidor de intervención para mejora en el clima laboral. Gerokomos. 2016; 27(2):48-52.

36. Daros W. ¿Qué es un marco teórico? Enfoques. 2002; 15(1): 73-112.

37. Cortés M. Cómo escribir la introducción de un artículo científico. Rev Colomb Ortop Traumatol. 2010; 24(2):83-5.

38. Kulakova O, Moreno B, Garrosa E. Universalidad del constructo del Maslach Burnout Inventory en un contexto latinoamericano. Acta Investig Psicológica. 2017; 7(2):2679-90. doi: https://doi.org/10.1016/j.aipprr.2017.05.001

39. Racionero-Torre C. Estrategias de intervención en profesionales de enfermería con síndrome de burnout. [Tesis]. Soria: Universidad de Valladolid; 2016.

40. Schmidt KH, Diestel S. Job demands and personal resources in their relations to indicators of job strain among nurses for older people. J Adv Nurs. 2013; 69(10):2185-95. Doi: http://dx.doi.org/10.1111/jan.12082

41. Romero Z, Cuba M. Síntomas somáticos en cuidadores de pacientes geriátricos con o sin sobrecarga, del área urbano-marginal Payet, Independencia, Lima, Perú. Rev Med Hered. 2013; 24(3):204-9.

42. Crespo M, Rivas MT. La evaluación de la carga del cuidador: una revisión más allá de la Escala de Zarit. Clínica y Salud. 2015; 26(1):9-16. Doi: http://dx.doi.org/10.1016/j.clysa.2014.07.002

43. Schmidt SG, Dichter MN, Bartholomeyczik S, Hasselhorn HM. The satisfaction with the quality of dementia care and the health, burnout and work ability of nurses: a longitudinal analysis of 50 german nursing homes. Geriatr Nurs (Minneap). 2014; 35(1):42-6. Doi: http://dx.doi.org/10.1016/j.gerinurse.2013.09.006

44. Liang YW, Hsieh Y, Lin YH, Chen WY. The impact of job stressors on health-related quality of life of nursing assistants in long-term care settings. Geriatr Nurs. 2014; 35(2):114-9. Doi: https://doi.org/10.1016/j. gerinurse.2013.11.001

45. Rouxel G, Michinov E, Dodeler V. The influence of work characteristics, emotional display rules and affectivity on burnout and job satisfaction: a survey among geriatric care workers. Int J Nurs Stud. 2016; 62:81-9. Doi: http://dx.doi.org/10.1016/j.ijnurstu.2016.07.010

46. Reyes K, González-Celis-Rangel ALM. Efectos de una intervención cognitivo-conductual para disminuir el burnout en cuidadores de ancianos institucionalizados. 2016; 9:15-23. Doi: $\underline{\text { http://dx.doi.org/10.5231/psy. }}$ writ.2015.1709

47. Gómez-Cantorna C, Clemente M, Bugallo-Carrera C, Gandoy-Crego M. Cuidados paliativos gerontológi- 
cos: influencia de las condiciones laborales y burnout en el personal de enfermería. Gerokomos. 2016; 27(3):91-6.

48. Peters V, Houkes I, de Rijk AE, Bohle PL, Engels JA, Nijhuis FJN. Which resources moderate the effects of demanding work schedules on nurses working in residential elder care? A longitudinal study. Int J Nurs Stud. 2016; 58:31-46. Doi: http://dx.doi.org/10.1016/j.ijnurstu.2016.01.008

49. Kolthoff KL, Hickman SE. Compassion fatigue among nurses working with older adults. Geriatr Nurs (Minneap). 2017; 38(2):106-9. Doi: http://dx.doi.org/10.1016/j.gerinurse.2016.08.003

50. Dhaini SR, Zúñiga F, Ausserhofer D, Simon M, Kunz R, De Geest S, et al. Are nursing home care workers' health and presenteeism associated with implicit rationing of care? A cross-sectional multi-site study. Geriatr Nurs (Minneap). 2017; 38(1):33-8. Doi: http://dx.doi.org/10.1016/j.gerinurse.2016.07.003 